Volume 10

October 2015

\title{
The Health Care Mess: How We Got Into It and What It Will Take to Get Out
}

Wendy K. Mariner

Follow this and additional works at: https://via.library.depaul.edu/jhcl

\section{Recommended Citation}

Wendy K. Mariner, The Health Care Mess: How We Got Into It and What It Will Take to Get Out, 10 DePaul J. Health Care L. 543 (2007)

Available at: https://via.library.depaul.edu/jhcl/vol10/iss4/5

This Book Reviews is brought to you for free and open access by the College of Law at Digital Commons@DePaul. It has been accepted for inclusion in DePaul Journal of Health Care Law by an authorized editor of Digital Commons@DePaul. For more information, please contact digitalservices@depaul.edu. 


\title{
BOOK REVIEW:
}

\section{THE HEALTH CARE MESS: HOW WE GOT INTO IT AND WHAT IT WILL TAKE TO GET OUT}

\author{
Authored by: Julius B. Richmond \& Rashi Fein
}

The Health Care Mess is a book that, using history, explains how it is that a nation as affluent as the United States and as scientifically advanced has been unable to construct a health care delivery and financing system that functions effectively for all the people. The book traces the history of medical education and contrasts the largely positive developments in medical education and research with the dysfunctional "health care mess" that leaves millions of our fellow citizens uninsured or under-insured even as health care costs and expenditures continue to increase more rapidly than general inflation or the growth of the economy. With access to care (especially primary care) shrinking and with availability of insurance declining as employers cut back their health care contributions, Americans face an impending crisis. With health care reform once again on the political agenda, The Health Care Mess contributes to a reasoned debate of alternatives by presenting their program to expand care and provide insurance for all. The book is written for the lay reader as well as for the health care professional.

\section{THE ROAD TO HEALTH REFORM}

\section{Reviewed by: Wendy K. Mariner**}

Like it or not, the next President's agenda will include health reform. One indicator is the escalating number of state laws to expand access to health insurance, control costs and monitor the quality of care. ${ }^{1}$ In

\footnotetext{
* Julius B. Richmond, M.D., is a founder of Head Start and the former Surgeon General under President Jimmy Carter. He is currently the John D. MacArthur Professor of Health Policy, Emeritus, at Harvard University. Professor Rashi Fein, Ph.D., is a Professor of Medical Economics, Emeritus, at Harvard Medical School.

** Professor of Health Law, Boston University School of Public Health; Professor of Law, Boston University School of Law; Professor of Socio-Medical Sciences and Community Medicine, Boston University School of Medicine, 715 Albany Street, Boston, MA 02118. J.D. Columbia Univ. School of Law; LL.M, New York Univ. School of Law; M.P.H., Harvard School of Public Health.
} 
April 2006, Massachusetts enacted a comprehensive health reform law intended to provide affordable health insurance to most of its uninsured residents. $^{2}$ The Massachusetts law is being discussed as a model for comprehensive and integrated reform, because it combines expanded Medicaid eligibility, a new shared small group and individual private health insurance market, and a requirement that individuals purchase health insurance if affordable (with subsidized premiums for lowincome individuals), with financing from cigarette taxes, small fees from employers who do not offer health insurance, and federal Medicaid funding. ${ }^{3}$ Vermont adopted its own version in May 2006, and California and other states are considering similar measures. ${ }^{4}$ This level of state house activity suggests that much of the population is ready for a change.

Significant change for all Americans, however, is not likely to come from the states alone. States are hampered by variable revenues to fund expanded programs, including possible future reductions in

${ }^{1}$ See, e.g., An Act to Provide Affordable Health Insurance to Small Businesses and Individuals and to Control Health Care Costs, 2003 Me. Laws 469 (codified in scattered sections of ME. REv. STAT. ANN. 2, 5, 22, and 24); State of Maine, Dirigo Health - Working for Maine, http:/www.dirigohealth.maine.gov (describing Maine's program); Act Relating to Health Care Affordability for Vermonters, 2006 Vt. Acts \& Resolves 191 (codified as amended in scattered sections of VT. STAT. ANN 2, 3, 8, 18, 32, and 33); Act Relating to Catamount Health 2006 Vt. Acts \& Resolves 190 (amending 2006 Vt. Acts \& Resolves 191). See generally Alice Burton et al., State Strategies to Expand Health Insurance Coverage: Trends and Lessons for Policymakers (2007), available

http://www.cmwf.org/publications/publications_show.htm?doc_id=461903.

${ }^{2}$ An Act Promoting Access to Affordable, Quality, Accountable Health Care, 2006 Mass. Acts 58 (codified as amended in scattered sections of MASS. GEN. LAwS 6A, $10,17,26,29,32,62,111,111 \mathrm{M}, 118 \mathrm{E}, 118 \mathrm{G}, 118 \mathrm{H}, 149,151 \mathrm{~F}, 175,176 \mathrm{~A}, 176 \mathrm{~B}$, 176G, 176J, 176M, 176N, and 176Q.). See John McDonough et al., The Third Wave of Massachusetts Health Care Access Reform, 25 HeALTH AFF., Sept. 14, 2006, at w420, http://content.healthaffairs.org/cgi/reprint/25/6/w420 (describing the Massachusetts law and its development).

3 See, e.g., Jonathan Gruber, The Massachusetts Health Care Revolution: A Local Start for Universal Access, HASTINGS CENTER REP., Sept.-Oct. 2006, at 14, 18 (arguing that the basic Massachusetts framework could be adapted to other states if financing can be obtained). But see John Holahan \& Linda Blumberg, Massachusetts Health Care Reform: A Look at the Issues, 25 HEALTH AFF., Sept. 14, 2006, at,w432, 43, http://content.healthaffairs.org/cgi/reprint/25/6/w432 (noting that "Massachusetts has advantages that most other states lack" in expanding insurance coverage)..

${ }^{4}$ See supra note 1; George C. Halvorson et al., A Proposal to Cover the Uninsured in California, 26 HEALTH AFF. Dec. 12, 2006, at w80, http://content.healthaffairs.org/cgi/reprint/26/1/w80 (proposing a model for California adapted from the Massachusetts model). 
federal dollars for Medicaid. ${ }^{5}$ Moreover, the Employee Retirement Income Security Act (ERISA) ${ }^{6}$ preempts state laws that force employers to provide health benefit plans for their employees, ${ }^{7}$ as well as reforms that alter the benefit structure or administration of such plans. ${ }^{8}$ This precludes states from using employer mandates to cover many uninsured residents, as Maryland was recently reminded. The Court of Appeals for the Fourth Circuit found that ERISA preempted Maryland's attempt to require Wal-Mart to contribute at least eight percent of payroll to its employee group health plan premiums or pay the difference to the state..$^{9}$ The Supreme Court has not yet reviewed such "pay-or-play" laws; however, their potential vulnerability to preemption has forced states to adopt piecemeal reforms that leave out major players like employers. Alternatives to employer mandates that would avoid ERISA preemption (and perhaps be fairer to small employers), such as a single-payer model or an income or payroll tax to fund insurance coverage or care, have yet to overcome political opposition.

Thus, health reform that offers universal access to reasonable care at an affordable cost probably is not possible unless it comes from Congress, and Congress is not likely to act without Presidential leadership. Even this may not be enough. As Julius B. Richmond and

${ }^{5}$ Robert Pear, Bush Seeks Big Medicare and Medicaid Savings, N.Y. TIMES, Feb. 2, 2007; Michael Abramowitz \& Lori Montgomery, Bush Plan Reins in Domestic Spending, WASH. POST, Feb. 6, 2007, at A1.

${ }^{6}$ Employee Retirement Income Security Act, 29 U.S.C. $\S \S 1001$ et seq. Section 514(a), codified at 29 U.S.C. $§ 1144(a)$, preempts "any and all State laws insofar as they may now or hereafter relate to any employee benefit plan" covered by ERISA..

${ }^{7}$ Standard Oil Co. v. Agsalud, 633 F.2d 760 ( $9^{\text {th }}$ Cir. 1980), aff'd mem., 454 U.S. 801 (1981) (holding that ERISA preempted Hawaii's Prepaid Health Care Act requiring employee benefit plans with prescribed health coverage); Fort Halifax Packing Co. v. Coyne, 482 U.S. 1, 12 (1987) (finding that a law requiring payment of severance pay upon certain plant closing did not establish an ERISA plan, because it did not entail an ongoing administrative scheme)..

${ }^{8}$ Shaw v. Delta Air Lines, Inc., 463 U.S. 85, 97 (1983) (a state law relates to an ERISA plan "if it has a connection with or reference to such a plan."); N.Y. State Conf. of Blue Cross \& Blue Shield Plans v. Travelers Ins. Co., 514 U.S. 645 (1995) (surcharges imposed on commercial health plans for hospital bills not preempted, because they do not preclude uniform benefits or administrative practices).

${ }^{9}$ Retail Industry Leaders Association v. Fielder, 2007 U.S. App. LEXIS 920 (4th Cir. 2007) (finding that section 514 of the Employee Retirement Income Security Act preempted Maryland's Fair Share Health Care Fund Act, 2006 Md. Laws 1, Md. Code Ann., Lab. \& Empl. §§ 8.5-101 to 107, because was intended to encourage WalMart to provide more health insurance coverage to its employees). 
Rashi Fein recount in The Health Care Mess, ${ }^{10}$ Presidents Nixon, Truman, and Kennedy championed national health insurance briefly, and President Clinton attempted national reform incorporating private insurance in 1993, all without success. ${ }^{11}$ Yet, the possibility of federal reform remains a perennial goal-tantalizing to some, anathema to others. $^{12}$

\section{GRIDLOCK IN HEALTH POLICY}

In December 2006, Senator Ron Wyden of Oregon introduced a federal bill modeled after the 2006 Massachusetts law, hoping to break "60 years of gridlock on a desperately needed overhaul of the nation's health care system." 13 How this gridlock arose and whether can be broken is the subject of The Health Care Mess.

It would be hard to find a more qualified team to diagnose America's health care ills. Dr. Richmond, a physician who first

10 Julius B. Richmond \& Rashi Fein, The Health Care Mess: How We Got into IT AND WHAT IT WILl TAKE TO GET OUT (2005) (hereinafter RichMOND \& FEIN).

1 See U.S. Domestic Policy Council, The President's Health Security Plan: The Clinton Blueprint (1993); Jacob S. Hacker, The Road to Nowhere: The Genesis of PResident Clinton's Plan for Health Security (1997) (suggesting reasons for the plan's failure to be enacted).

12 Health policy analyses often cluster in times of national debate over health insurance: the 1960's, when Congress produced Medicare and Medicaid; the early 1970's, when President Nixon considered national health insurance; and the late 1970's, when President Carter advocated cost controls and planning measures. See, e.g., Uwe E. Reinhardt, Health Insurance for the Nation's Poor, HEALTH AfF. 101 (Spring 1978) (proposing a form of universal health insurance coverage); ALAIN C. Enthoven, Health Plan: The Only Practical Solution to the Soaring Cost OF MEDICAL CARE (1980) (proposing competing health maintenance organizations); National Health Insurance: What Now? What Later? What Never? (Mark V. Pauly, ed. 1980) (analyzing the advantages and disadvantages of national health insurance); HENRY J. Aaron \& William B. SCHWARTZ, THE PaINFul PRESCRIPTION: RATIONING HOSPITAL CARE (1984) (describing the role of technology in increasing costs and the need for rationing care); RASHI FEIN, MEDICAL CARE, Medical Costs: The SeARCh fOr a Health Insurance Policy (1986) (analyzing the rise in health care costs and options for reform); HISTORY AND HEALTH POLICY IN THE UNITED STATES (Rosemary A. Stevens et al. eds., 2006) (a collection of essays on the history of health policy); HEALTHY, WEALTHY \& FAIR: HEALTH CARE AND THE GOOD SOCIETY (James A. Morone \& Lawrence R. Jacobs eds., 2005) (analyzing the health of Americans and obstacles to improvement).

13 Press Release, Senator Ron Wyden, Wyden Proposes Historic New Health Care Plan (Dec. 13, 2006), available at http://wyden.senate.gov/media/2006/12132006_Healthy_Americans_Act.htm (announcing proposal of The Healthy Americans Act). 
established the Head Start Program and Neighborhood Health Centers and later served as Assistant Secretary of Health and Surgeon General under President Jimmy Carter, remains sensitive to the effect of national policy on real people. Professor Fein, an economist, was a member of President John F. Kennedy's Council of Economic Advisors and also counseled Senator Edward Kennedy and the Committee for National Health Insurance. While not in Washington, both men taught at Harvard Medical School. The authors wrote their book because they believe that there are enough people who want change and in order to bring about change, the public needs to understand "how we got here." $" 14$

Each of the first three parts of the book examines an historical era in which salient features of today's health care system emerged: 1900 - 1965, "the coming of age of American medicine," 15 in which scientific advances initiated an expanding supply of promising care; 1965 - 1985, when insurance became an immutable financing method and costs rose in the wake of Medicare; and 1985 - 2005, in which regulatory efforts subsided, while an entrepreneurial ethos reshaped traditional relationships. A common theme in these chapters is how the supply side and the demand side of health care developed in different spheres in response to scientific, economic, and political events, and how they resist integration and drive up costs.

Chapter Two includes a succinct summary of the development of insurance during World War II, including elements that largely determined the shape of health insurance today, such as tax treatment, placing the locus of the insurance pool in employers, and its focus on hospital-based care. ${ }^{16}$ In contrast, national insurance programs in Western Europe took root before the private insurance industry had much presence in health, which left considerable room for government supervision or control without having to battle large entrenched interests. ${ }^{17}$ Thus, the insurance industry plays a decisive role in American health policy today, unlike its more subordinate, functional position within national health systems elsewhere.

The historical chapters go a long way to explain why health care policy in the United States remains in perpetual gridlock. The deeper

\footnotetext{
14 RichMOND \& FEIN at $1-2$.

${ }^{15}$ RICHMOND \& FEIN at 5.

${ }^{16}$ RICHMOND \& FEIN at 36-9.

${ }^{17}$ RICHMOND \& FEIN at 234.
} 
the roots of each stakeholder in the system, the more difficult it is to change its role.

\section{CHOOSING NOT TO CHOOSE}

Despite different historical circumstances, debates over health policy in America reprise recurrent disputes grounded in different political philosophies. ${ }^{18}$ At one extreme are those who believe that only an integrated single-payer system run by the federal government can provide universal access to care. ${ }^{19}$ At the other extreme are those who believe that the market remains the best method of distributing care, with little regulation by the state or federal government. ${ }^{20}$ Even those in the middle tend to divide according to whether they believe that health care is a moral, if not legal, human right, requiring at least basic care available to all according to need, ${ }^{21}$ or whether they believe that health care is more akin to an economic commodity that should be distributed through market mechanisms with only limited government intervention to ensure access by those unable to pay market prices. ${ }^{22}$

${ }^{18}$ Examples of the rich literature on health policy reform since 1990 include VICTOR R. Fuchs, The Future of Health Policy (1993); Eli Ginzberg, The Road to Reform: The Future of Health Care IN AMERICA (1994); El GinzberG, MEdical Gridlock and HeAlth REForm (1994); THEOdore R. MARMor, Understanding Health CARE Reform (1994). See also infra notes 10-12.

${ }^{19}$ See, e.g., David V. Himmelstein et al., A National Health Program for the United States: A Physician's Proposal, 320 NEW ENG. J. MED. 102 (1989); VInCENTE Navarro, The Politics of Health Policy: The U.S. Reforms 1980-1994 (1994); Proposal of the Physicians' Working Group for Single-Payer National Health Insurance, 290 JAMA 798 (2004)..

${ }^{20}$ See, e.g., Richard EPSTEIn, Mortal Peril: OUR Inalienable Right to Health CARE? (1997) (arguing against redistribution of income and regulated markets); Clark C. Havighurst, Health Care Choices: Private Contracts as Instruments of Health Reform (1995); Paul J. Feldstein, Health Policy Issues: An ECONOMIC Perspective on HeAlth ReForm (1994); Paul M. Ellwood et al., The Jackson Hole Initiative for a Twenty-First Century American Health Care System, 1 Health ECON. 158 (1992).

21 See, e.g., Institute of MEDICINE, COMMITTEE ON THE CONSEQUENCES OF UNINSURANCE, INSURING AMERICA's HEALTh (2004); DAVID CUTLER, YOUR MONEY OR Your Life: STRONG MEdicine for America's Health Care System (2004); George J. Annas, Some Choice: Law, Medicine and the Market (1998); The Future of the U.S. Health Care System: Who Will Care for the PoOr aNd UNINSURED? (Stuart H. Altman et al. eds., 1998).

22 See, e.g., David Mechanic, The Truth about Health Care: Why Health REFORM IS NOT WORKING IN AMERICA (2006); Alain C. Enthoven, EmploymentBased Health Insurance Is Failing: Now What?, HeALTH AFF., May 28, 2003, at W3237, 240, http://content.healthaffairs.org/cgi/reprint/hlthaff.w3.237v1.pdf. 
Instead of repeating the same debates over whether health care is a right or a privilege-a social responsibility or an economic commodity-Richmond and Fein explain events that moved the country toward one view or the other. There have been voices for each point of view since the early twentieth century. ${ }^{23}$ For example, in the 1960's, Robert Taft proposed private accounts, much like today's health savings accounts (HSAs), as an alternative to enacting Medicare. $^{24}$ It may surprise many, therefore, to see how often economics and politics subdued those voices in order to expand access to care, from the adoption of Medicare to the State Child Health Insurance Program.

Still, at a fundamental level, things changed little in the last decades of the twentieth century. Every time national health care expenditures ticked up another percentage point of the Gross Domestic Product, some commentators predicted that, at last, the country had to adopt major reform. ${ }^{25}$ But by the 1970 's, the modern health care system had solidified sufficiently to resist dramatic upheaval. Almost every stakeholder can find something to dislike in any proposal for national health insurance, so that it has become virtually impossible to achieve unity on any single approach. ${ }^{26}$

The authors argue persuasively that American policy makers have refused to choose between irreconcilable approaches to increasing access to care and reducing expenditures. Instead they have adopted both: (1) regulating some costs ("ineffectively and by attempting to constrain demand"), and (2) increasing resources by expanding "supply and expenditures." 27 Avoiding choice left "the market as the ultimate arbiter.",28

\footnotetext{
${ }^{23}$ RICHMOND \& FEIN at 30.

24 RICHMOND \& FEIN at 46-7.

25 See, e.g., Daniel Callahan, Setting limits: Medical Goals in an Aging SOCIETY (1987). See generally NORMAn Daniels, Just HEALTH CARE (1985); Larry R. Churchill, Rationing Health Care IN AMERICA: Perceptions and Principles of Justice (1987); Paul T. Menzel, Strong Medicine: The Ethical RATIONING OF HEALTH CARE (1990).

${ }^{26}$ RICHMOND \& FEIN at 71; see also Mark A. Peterson, The Congressional Graveyard for Health Care Reform, in HEAlthy, WeAlthy \& FAIR: HeAlth CARE AND THE GOOD SOCIETY 205, 211-17 (James A. Morone \& Lawrence R. Jacobs eds., 2005) (describing barriers to coalition building in Congress).

${ }^{27}$ RICHMOND \& FEIN at 124.

${ }^{28}$ RICHMOND \& FEIN at 124-5; see also Robert J. Blendon et al., Americans' Views of the Uninsured: An Era for Hybrid Proposals, HEALTH AFF., Aug. 27, 2003, at W3405, http://content.healthaffairs.org/cgi/content/full/hlthaff.w3.405v1/DC1 (reporting on public opinion surveys finding similarly ambivalent views).
} 
Unlike markets for other products, however, increased supply and competition in health care have rarely led to lower prices for medical care. ${ }^{29}$ New medical technologies often are more expensive than existing technologies, and many are used in addition to, rather than instead of, earlier technology. ${ }^{30}$ Moreover, as Richmond and Fein note, "[t]he market is not a redistributive device," because it necessarily allocates goods according to ability to pay. ${ }^{31}$ Thus, markets cannot solve the most pressing problem in health care today: care is simply unaffordable for millions of Americans. Most market reforms target demand. For example, economic incentives like co-payments and deductibles and so-called consumer-driven health plans are intended to discourage patients from buying unnecessary care. ${ }^{32}$ Despite widespread recognition that the health care system wastes a significant amount of resources on unnecessary services, both administrative and medical, most economic incentives are far too crude to shape individual choices into the most efficient use of resources. Moreover, Americans sometimes reject market limitations on access to care, as the backlash to many managed care constraints illustrated in the 1990's. ${ }^{33}$

${ }^{29}$ See Milton I. Roemer, Bed Supply and Hospital Utilization: A Natural Experiment, 35 HoSPITALS 36 (Nov. 1, 1961) (first arguing that increased hospital resources result in increased hospital stays, which became known as Roemer's Law that "a bed built is a bed filled"). See also Randall Bovbjerg, Problems and Prospects for Health Planning: The Importance of Incentives, Standards and Procedures in Certificate of Need, 1978 UTAH L. REV. 83, ("This phenomenon of demand creation is sometimes called 'Roemer's Law' . . . after the man who first reported that hospitalization utilization was affected by the number of beds available to be utilized.")..

${ }^{30}$ Henry J. Aaron, In Serious and Unstable Condition: Financing American HEALTH CARE (1991) (analyzing technology costs).

${ }^{31}$ RICHMOND \& FEIN at 229.

${ }^{32}$ See generally Wendy K. Mariner, Can Consumer-Choice Plans Satisfy Patients? Problems with Theory and Practice in Health Insurance Contracts, 69 BROOK. L. REV. 485 (2004) (describing consumer-driven plans and arguing that they effectively ask patients to ration their own care).

${ }^{33}$ See, e.g., Marc A. Rodwin, Backlash as Prelude to Managing Managed Care, 24 Health POL. POL'Y \& L. 1115 (1999) (describing the "backlash" of consumer objections to limits imposed by managed care); Uwe E. Reinhardt, Consumer Choice under "Private Health Care Regulation," in Regulating Managed CARE: THEORY, PRACTICE, AND FUTURE OPTIONS 91-116 (Stuart H. Altman et al., eds., 1999) (arguing that employees resisted such limits in part because they perceived their care as free in the past). For a more personalized description of objections to managed care, see GEORgE ANDERS, HEAlth AgAINST WeAlth: HMOs AND THE BREAKDOWN OF MEDICAL TRUST (1996), 
Richmond and Fein's summary of medical education could just as well be describing our persistent ambivalence about the health system as a whole:

The American dilemma, on the one hand, of wanting to rely on market forces yet nevertheless being skeptical about their efficacy, and, on the other hand, wanting something akin to the results of rational planning while rejecting planners and planning mechanisms - that is, the dilemma of wanting lower expenditures while rejecting control and budgeting mechanisms-shaped how we dealt, and did not deal, with graduate medical education. ${ }^{34}$

Richmond and Fein pay special attention to physicians, and not entirely because they have spent many years at a medical school. ${ }^{35}$ They demonstrate how the division of the medical profession into academics and practitioners influenced both the economics and politics of health reform. The post-World War II growth in National Institutes of Health funding reshaped medical schools, giving substantial control to funded researchers and making medical schools depend on federal funding to train physicians, conduct research, and pay faculty. ${ }^{36}$ Academic physicians typically remain more comfortable with government financing than their colleagues in the private practice of medicine. Traditional organized medicine-practicing physicians represented by the American Medical Association (AMA)-resisted government participation in financing the delivery of care to patients. This left personal care - the demand side of the medical system, if you will-in the private market, while academic medicine (and a growing pharmaceutical and medical device industry) - the supply sidepumped out more and more expensive therapies and procedures, with the attitude that more is better. Practicing physicians and patients struggled to pay for it all. The need for more financing for care gave

\footnotetext{
${ }^{34}$ RICHMOND \& FEIN at 119.

${ }^{35}$ Chapter 1 begins with the Flexner Report and how it reconfigured medical education and reduced the physician-patient ratio. RICHMOND \& FEIN at 10 . See Abraham Flexner, Medical Education in the United States and Canada (New York: Carnegie Foundation for the Advancement of Teaching, Bulletin No. 4, 1910). Since today's American medical schools seem to entrench, rather than change, traditional behaviors, one might have hoped for a discussion of better ways to educate health care professionals, but that is probably expecting too much of a short volume on health policy.

${ }^{36}$ RICHMOND \& FEIN at 24-5.
} 
insurers increasing leverage over payment for services, but, significantly, not over continued expansion of the supply of services themselves. For its part, the AMA has been increasingly marginalized, beginning with its unsuccessful opposition to Medicare, and was unprepared to influence the private insurance market. ${ }^{37}$ As my colleague, Professor Fran Miller, once quipped, "While the AMA was standing guard against socialism, it got blindsided by capitalism." The current situation leaves little room for money-saving reforms.

The American insurance industry's growth encouraged more entrepreneurial companies, including for-profit hospitals and managed care companies, to enter the health care system. ${ }^{38}$ Richmond and Fein are critical of some aspects of this industry, arguing that its values are detrimental to patients and providers. ${ }^{39}$ Indeed, the late 1980's and early 1990's saw a paradigm shift when physicians became "providers" or "vendors" and patients became "consumers" or "covered lives" with "responsibilities" as well as rights. ${ }^{40}$ Richmond and Fein conclude that competition among providers and among insurers has not produced the promised quality improvements or lower costs, but, rather, has wasted resources and increased costs. ${ }^{41}$ Moreover, the continued focus on limiting demand, without significantly constraining supply or its cost, is bound to fail to control expenditures, especially for something people feel they need. ${ }^{42}$

The authors share a vision of America, which, they declare up front, includes the premise "that one's income and wealth should not

${ }^{37}$ RICHMOND \& FEIN at 130.

${ }^{38}$ RICHMOND \& FEIN at 135.

39 RICHMOND \& FEIN at 242. For other critics, see e.g., WALTER ZELMAN, THE Changing Health Care MarketPlace: Private Ventures, Public Interests (1996) (describing the rise of entrepreneurialism and managed care); MAGGIE Mahar, Money-Driven Medicine: The Real Reason Health Care Costs So MUCH (2006) (arguing that for-profit corporate entities with no patient contact drive up costs more than physicians and non-profit hospitals).

${ }^{40}$ See generally George J. Annas, Reframing the Debate on Health Care by Replacing Our Metaphors, 332 NEw ENG. J. MED. 744 (1995) (arguing that metaphors shape the content of policy analysis); Edmund D. Pellegrino, Words Can Hurt You: Some Reflections on the Metaphors of Managed Care, 7 J. AM. BOARD FAM. PRAC. 505 (1994) (arguing that some managed care terms dehumanize patients and physicians).

${ }^{41}$ RICHMOND \& FEIN at 222.

${ }^{42}$ RICHMOND \& FEIN at 229 ("health issues are about 'need,' not about the economic concept of 'demand.'"); see also HENRY J. AARON \& William B. SCHWARTZ, CAN We SAy No? The Challenge of RATIONING CaRe (2005) (arguing that any serious effort to reduce costs may require rationing care). 
determine the amount and quality of care one receives..." 43 Because income and wealth do determine the amount, if not always the quality, of care Americans receive, the authors openly deplore "the wide disparities not only in health care but in income, education, housing and other important factors that affect well-being and opportunity." ${ }^{\text {"While }}$ this view does not distort their presentation of facts or history, it strongly shapes their prescriptions for change.

\section{BREAKING GRIDLOCK: RECOMMENDATIONS FOR REFORM}

In the book's fourth and last part, Richmond and Fein propose how to get out of the "health care mess" in the hope of reviving "the debate about how to proceed toward the goal of equitable health care." ${ }^{, 45}$ They offer two solutions to the problem of the uninsured. Their preference is for a federal solution, specifically a universal social insurance program-Medicare for all-because it would be the fairest approach, covering everyone, and most efficient, avoiding unnecessary administrative complexity and cost that private insurance entails. ${ }^{46}$ However, they recognize, on the basis of experience, much of it recounted in the book, that the U.S. will probably not go there until it has exhausted every other more expensive, complicated option. Although they discount the need for massive new taxes to fund coverage of the uninsured, they recognize the resistance of both legislators and much of the public to taxation in lieu of premium payments. Moreover, many voters may be wary of transitioning to a health plan unlinked from employment, where funds would flow to government rather than through employers to insurers. The 1993 commercials featuring Harry and Louise shaking their heads and saying "There must be some other way" capitalized on public fear of government control over health care and contributed to the Clinton's plan's demise. $^{47}$

As a more politically acceptable alternative, the authors propose an incremental approach, modeled after the Federal Employees Health Benefits Program (FEHBP), which offers federal employees a choice of

\footnotetext{
${ }^{43}$ RICHMOND \& FEIN at 4.

${ }^{44} \mathrm{Id}$.

${ }^{45} I d$.

${ }^{46}$ RICHMOND \& FEIN at 243.

${ }^{47}$ See www.harryandlouise.org. for the ads.
} 
approved private health insurance and managed care plans. ${ }^{48}$ At each stage, triggered automatically under new federal legislation, a new group of individuals would choose enrollment in one of the FEHBP private health insurance plans. ${ }^{49}$ The authors do not prescribe which groups should be enrolled first, but suggest beginning with children or the 45 million uninsured Americans, or by rolling "Medicaid recipients, Medicare beneficiaries, and other individuals with federally financed coverage" into a single unified program. ${ }^{50}$ This could cover more than 175 million Americans. Individuals with employment-based group coverage also could be allowed to enroll in the larger federal program if they wished. It remains unclear whether employers would be willing to decouple health insurance from employment. ${ }^{51}$ If they are, insurers might be able to spread risks across larger insurance pools and offer affordable premiums.

Under Richmond and Fein's proposal, health plans would have to offer open enrollment, accepting members regardless of health status. This approach would preserve the private insurance market, but require complex risk adjustments to enable insurers with a disproportionate number of sick enrollees to charge competitive premiums. ${ }^{52}$ With some prescience, they favor requiring everyone to buy insurance, with government subsidies for low-income individuals - similar to the package of reforms enacted by Massachusetts in $2006,{ }^{53}$ and proposed by Senator Ron Wyden. ${ }^{54}$

Of course, it will not be enough to remove the financial barriers to health care. ${ }^{55}$ Other changes are necessary to ensure "comprehensive

${ }^{48}$ RICHMOND \& FEIN at 254; see 5 U.S.C. $\$ \S 8901-8914$. The FEHBP covers nine million federal employees, retirees, and their families at an annual cost to the federal government of about $\$ 20$ billion. U.S. Office of Personnel Management, Federal Employees Health Benefits Plan, http://www.opm.gov/insure/health/ (last visited March 27, 2007).

${ }^{49}$ RICHMOND \& FEIN at 254.

${ }^{50}$ Id .

${ }^{51}$ See Robert S. Galvin \& Suzanne Delbanco, Between A Rock and A Hard Place: Understanding The Employer Mind-Set, 25(6) HEALTH AFFAIRS 1548 (Nov./Dec. 2006) (arguing that employers are looking for ways to get out of the health benefits business but reluctant to hand cost control over to government). But see Jonathan Cohn, What's the One Thing Big Business and the Left Have in Common?, N.Y. TIMES MAGAZINE 45; Apr. 1, 2007 (describing a business leader's cooperation to develop Sen. Wyden's federal reform bill).

${ }^{52}$ RICHMOND \& FEIN at 253.

${ }^{53}$ See infra note 2.

${ }^{54}$ See infra note 13.

${ }^{55}$ RiCHMOND \& FEIN at 220. 
services of high quality to [meet] the needs of the population without wasting resources." 56 Richmond and Fein hope that public health measures will reduce expenditures in the twenty-first century, just as it contributed as much or more than medicine to increasing life expectancy in the twentieth century. ${ }^{57}$ At best, perhaps, preventive measures may result in the compression of morbidity-postponing debilitating illness until very late in life and for a shorter period. Whether they will reduce costs is less certain. ${ }^{58}$ Public health and the quest for fitness have permeated much of everyday life in America today. ${ }^{59}$ If services to promote health and fitness become part of health insurance coverage, however, it will be difficult to place any boundaries on the demand for services or their costs. At the same time, if public health measures push expensive illness to later ages, then the federal government will have an even greater incentive to bring the younger, healthier population into its risk pool in order to spread the costs of the population it finances.

\section{CONCLUSION}

The path to reform is highly contingent. The authors make clear that "timing is everything." 60 President Lyndon Johnson was able to push an astonishing range of health and civil rights legislation through Congress in the late 1960's. The momentum for expanding Medicare and Medicaid into a more universal health insurance system was lost, however, as the Vietnam war began to absorb Johnson's attention and a rising share of the federal budget. ${ }^{61}$ Contemporary proposals for health reform might fall prey to the war in Iraq, which continues to dominate

\footnotetext{
${ }^{56}$ RICHMOND \& FEIN at 220.

${ }^{57}$ RICHMOND \& FEIN at 91.

58 See Centers for Disease Control and Prevention \& The Merck Company Foundation, State of Aging and Health in America 2007 Report 5 (2007) (noting that the "cost of providing health care for one person aged 65 or older is three to five times greater than the cost for someone younger than 65"), available at http://www.cdc.gov/aging/saha.htm; see generally LOUISE B. RuSsELL, Is PREVENTION BETTER THAN CURE? (1986) (questioning the efficacy of some prevention measures).

59 See generally Alan Peterson \& Deborah Lupton, The New Public Health: HEALTH AND SELF IN THE AGE OF RISK (1996) (describing the penetration of public health concerns into most aspects of daily life); ARTHUR J. BARSKY, WORRIED SICK: OUR TROUBLED QUEST FOR WELLNESS (1988) (arguing that population health improves, Americans focus on lesser risks).

${ }^{60}$ RICHMOND \& FEIN at 234.

${ }^{61}$ RICHMOND \& FEIN at 56.
} 
public opinion, the Bush administration's attention, and the federal budget.

Another impediment to reform is its complexity. It is difficult to focus public attention on complex problems that require complex solutions. The Clinton health plan began to lose momentum when its advocates could not explain it in less than thirty minutes. Where reforms are complicated and entail multiple options, people may abandon the effort of even grappling with the problem, or as Aaron Wildavsky reportedly put it, "No solution, no problem." 62

Finally, there is the problem of choosing between incremental reform and revolutionary change. Although the American political system seems geared to incrementalism, lasting changes in health policy, like Medicare, appeared as sweeping reforms spurred by popular opinion that challenged convention wisdom. Thus, our history could support gradual modifications or dramatic possibilities or continued gridlock.

Richmond and Fein know as well as (or better than) anyone how hard it is to change our system, yet they remain remarkably optimistic about the possibility of reform. The fact that Massachusetts and other states have made the effort may mean that the country is indeed ready for change. However, Massachusetts learned, perhaps from the country's experience with Medicare, that it was necessary to engage all the stakeholders in the process of developing new policy. It took years to build consensus among business, insurance, consumers, providers, advocacy groups, and legislators on key trade-offs. At the national level, it will take political will both to build that consensus and put it into action. Finally, it will take strong Presidential leadership.

We may have an opportunity for strong Presidential leadership shortly. If so, The Health Care Mess should be on the new president's reading list. It is a succinct and comprehensive analysis of the American health care system, with lessons that should not be ignored. Even those who might disagree with its specific recommendations would do well to pay close attention to the need for change.

${ }^{62}$ Quoted by James Morone in his keynote address to the Boston University School of Law conference, "Extraordinary Powers in Ordinary Times," Boston, MA, September $29,2006$. 